\title{
Estimation of Infiltration Rates of Saturated Soils at Selected Sites in the Caloosahatchee River Basin, Southwestern Florida
}

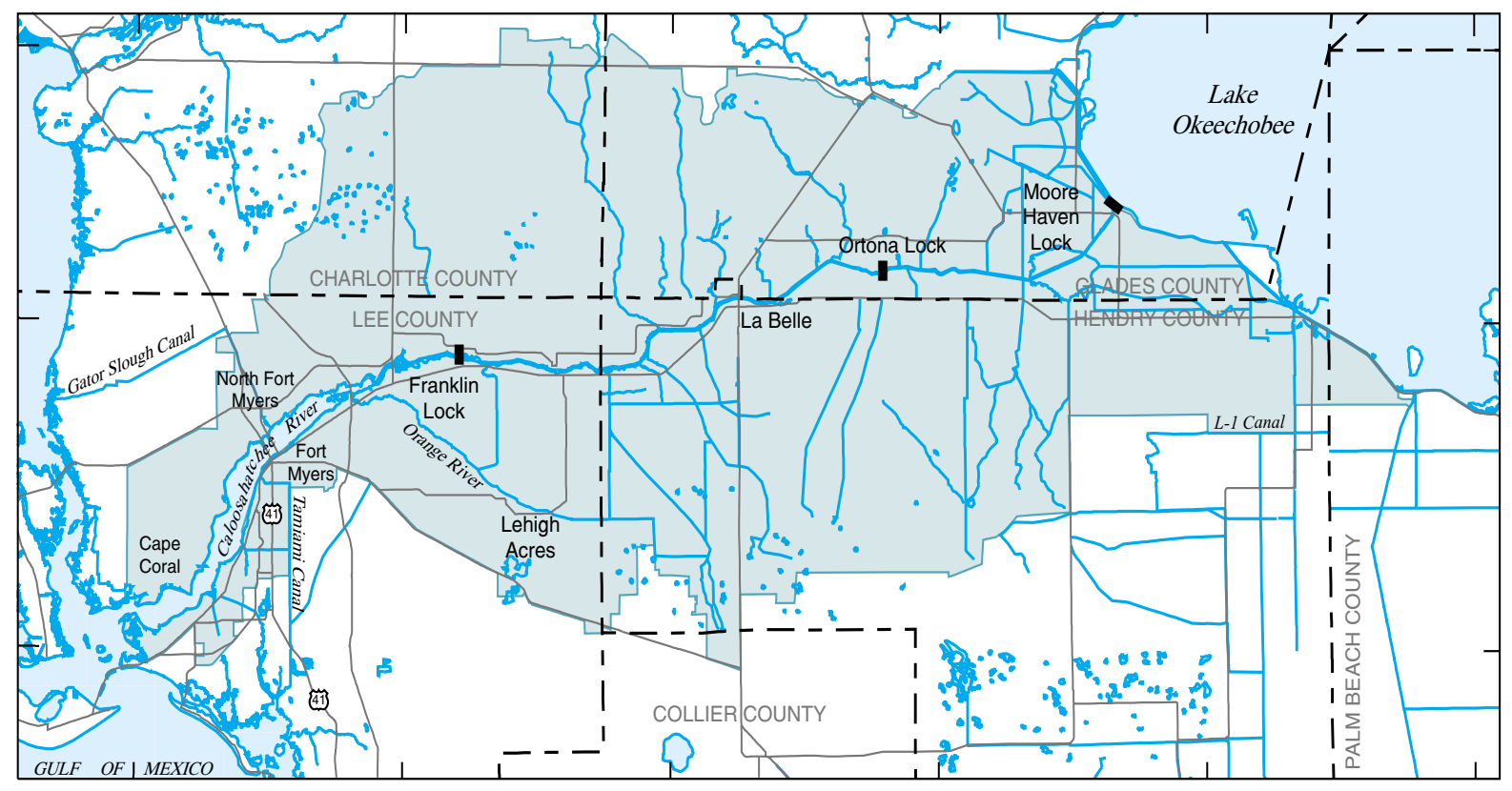

\section{U.S. GEOLOGICAL SURVEY}

Open-File Report 01-65

Prepared in cooperation with the

SOUTH FLORIDA WATER MANAGEMENT DISTRICT 


\title{
Estimation of Infiltration Rates of Saturated Soils at Selected Sites in the Caloosahatchee River Basin, Southwestern Florida
}

\author{
By Pamela A. Telis
}

U.S. GEOLOGICAL SURVEY

Open-File Report 01-65

Prepared in cooperation with the

South Florida Water Management District 


\section{U.S. DEPARTMENT OF THE INTERIOR \\ GALE A. NORTON, Secretary}

U.S. GEOLOGICAL SURVEY

CHARLES G. GROAT, Director

Any use of trade, product, or firm names in this publication is for descriptive purposes only and does not imply endorsement by the U.S. Geological Survey.

For additional information write to:

District Chief

U.S. Geological Survey

Suite 3015

227 North Bronough Street

Tallahassee, FL 32301
Copies of this report can be purchased from:

U.S. Geological Survey

Branch of Information Services

Box 25286

Federal Center

Denver, CO 80225

888-ASK-USGS

Additional information about water resources in Florida is available on the World Wide Web at http://fl.water.usgs.gov 


\section{CONTENTS}

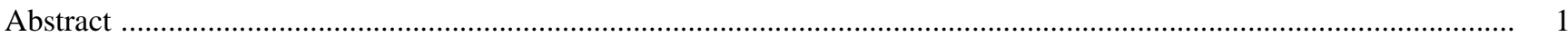

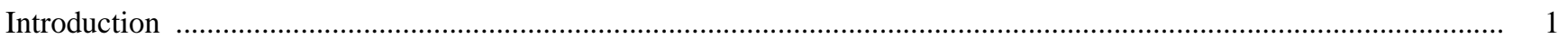

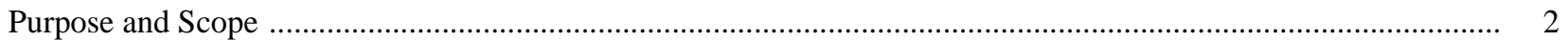

Soil Characteristics and Landscape Groups ............................................................................................ 2

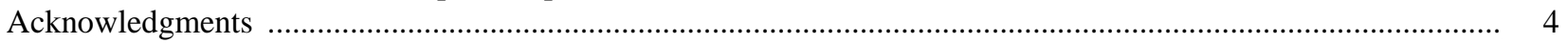

Estimating Infiltration Rates of Saturated Soils ............................................................................................. 5

Soil Infiltration Measurements ........................................................................................................... 5

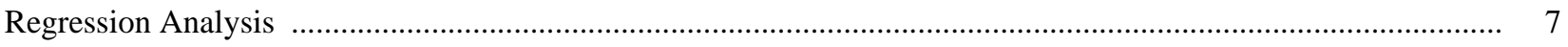

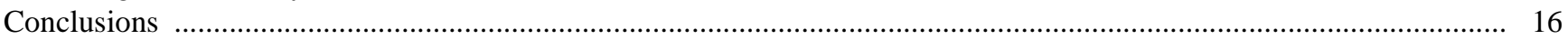

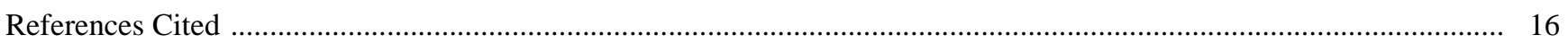

\section{FIGURES}

1. Map showing Caloosahatchee River Basin and location of soil infiltration sites in southwestern Florida ............ 3

2. Diagram showing double-ring infiltrometer setup .................................................................................. 7

3. Plots showing soil infiltration rate as a function of time for sites where data could not be fitted to Horton's

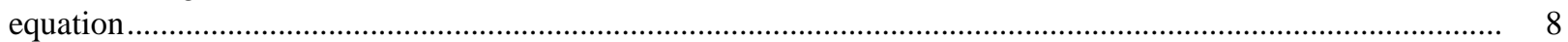

4. Plots showing soil infiltration rate as a function of time for sites fitted to Horton's equation ............................ 10

5. Plots showing estimated saturated soil infiltration rates for sites by landscape group compared with lowest saturated vertical hydraulic conductivity used in the integrated surface-water and ground-water model

\section{TABLES}

1. Typical soil profiles and associated hydraulic conductivities used in the integrated surface-water and ground-water model for various landscape groups

2. Description of soil infiltration sites in the Caloosahatchee River Basin ........................................................ 6

3. Estimates of infiltration rates of saturated soils based on average incremental infiltration rates for time periods greater than 20 minutes

4. Estimates of infiltration rates of saturated soils based on regression analysis 


\title{
Estimation of Infiltration Rates of Saturated Soils at Selected Sites in the Caloosahatchee River Basin
}

\author{
By Pamela A. Telis
}

\section{ABSTRACT}

Soil infiltration measurements were made at 23 sites in the Caloosahatchee River Basin in Glades, Hendry, and Lee Counties in southwestern Florida. The sandy soils of the basin are characterized by high infiltration rates limited in some areas by a high water table during the wet season.

Because soil characteristics are similar within the basin, soils are classified by landscape group based on landscape cover and associated drainage. In accordance with this designation by the South Florida Water Management District, 11 sites are classified in the rock landscape group, 7 in the flatwoods landscape group, 4 in the slough landscape group, and 1 in the depression landscape group.

Data for 16 sites were fit to Horton's equation by using a regression analysis to estimate the infiltration rates of saturated soils. For some sites, an outlier value was removed prior to the regression analysis. Seven of the sites did not yield data that fit Horton's equation. The flatness of the plotted data suggests that saturated conditions may have been reached early in the test. The infiltration rate of saturated soils for these sites was estimated by averaging the data collected after the first 20 minutes of the test.

For all sites, the estimated infiltration rates of saturated soils ranged from 9.8 to 115 centimeters per hour in flatwoods, 3.4 to 66 centimeters per hour in rock, and 2.5 to 55 centimeters per hour in slough. The estimated soil infiltration rate at the one site in the depression was 181 centimeters per hour. Five sites were located on irrigation control berms where infiltration rates of the highly com- pacted and rocky soil may not represent the rates of less disturbed soils at sites within the same landscape groups.

\section{INTRODUCTION}

The Caloosahatchee River has been dredged, lengthened, and deepened over the past century to drain water from Lake Okeechobee into the Gulf of Mexico. Additionally, the river has been channelized to:

(1) meet agricultural demands in the basin for irrigation and drainage for crops, such as citrus and sugar cane;

(2) transport goods within the basin and across the state of Florida; and (3) provide reliable, high-quality water supply to expanding urban centers of Fort Myers and smaller communities. Today (2000), the Caloosahatchee River Basin serves an urban area of more than 250,000 people and an agricultural area that encompasses more than $1,295 \mathrm{~km}^{2}$ (square kilometers) in southwestern Florida. The growth in population is expected to continue and increase dramatically through 2020. Agricultural land acreage also is expected to expand as unimproved pasture and other lands become productive through irrigation and drainage.

Beginning in 1997, development of a watermanagement plan for the Caloosahatchee River Basin was implemented to assist officials in the decisionmaking process regarding potential water-supply needs in southwestern Florida through 2020. The objectives of the plan are to estimate the future water-supply needs of urban and agricultural areas, weigh those demands against historically used water sources, and identify areas where the demands cannot be met without causing harm to the water resources and environment (Caloosahatchee Advisory Committee, written commun., 1999). 
In accordance with this water-management plan, an integrated surface-water and ground-water (ISWGW) model was constructed to examine current and future water usage and sources and to test watermanagement techniques in the Caloosahatchee River Basin. The ISWGW model, developed by the Danish Hydrologic Institute, uses the MikeSHE model (Jacobsen, 1999), which simulates surface-water and groundwater interaction within a watershed. Model components used for the simulation include irrigation schemes, seasonal crop evapotranspiration demands, and infiltration through various soil profiles.

In 1998, the U.S. Geological Survey (USGS), in cooperation with the South Florida Water Management District (SFWMD), began a study to support the ISWGW model development effort by collecting and analyzing data to estimate saturated soil infiltration rates at selected sites in the Caloosahatchee River Basin. The vertical hydraulic conductivity of saturated soil, an input parameter to the MikeSHE model, was estimated from these measured infiltration rates under specified field conditions.

\section{Purpose and Scope}

The purpose of this report is to present estimates of the infiltration rates of saturated soils at selected sites within the Caloosahatchee River Basin in Lee, Hendry, and Glades Counties in southwestern Florida. The model area covers part of the basin that drains to the freshwater portion of the river between Moore Haven Lock and Franklin Lock (fig. 1).

Saturated soil infiltration rates were estimated at 23 sites in the study area using a double-ring infiltrometer. Time-series plots were generated for all of the sites. Horton's equation was used with a regression analysis at 16 sites to estimate the infiltration rates of the saturated soils; outliers were removed from 5 of these sites before the regression analysis was made. Horton's equation could not be used to describe data for the remaining seven sites. The nearly constant infiltration rates measured during the tests at these sites were averaged to estimate the magnitude of the infiltration rate of the saturated soils. Test results, presented herein, are arranged by landscape group as classified by the SFWMD.

\section{Soil Characteristics and Landscape Groups}

Most of the soils in the Caloosahatchee River Basin are characterized as shallow and sandy and have high infiltration rates that are limited in some areas by a high water table during the wet season. The nearly 70 different soil types in the model area have similar physical characteristics and hydraulic characteristics. Because of these similarities, the landscape cover and associated drainage were the principal attributes for combining soil types into hydrologic response groups. The landscape groups (Eric Flaig, South Florida Water Management District, written commun., 1998) used for this study are described below.

- Depression - Occurs in flatwoods and marsh and pond landscapes as shallow dips or depressions in the land surface where drainage is limited. Depressions are characterized by high organic matter content in the surface horizon that reduces infiltration and increases runoff.

- Flatwoods - Nearly level areas where scattered to numerous pine trees are common and saw palmetto, gallberry, and other woody plants flourish throughout the region. Soils associated with this landscape group include Immokalee, Myakka, and Oldsmar. Typically, this poorly drained soil occurs on broad irregular areas with a slope of less than 2 percent. The water table may be within $254 \mathrm{~mm}$ (millimeters) of the soil surface for up to 5 months. During the dry season, the water table is at least $1,270 \mathrm{~mm}$ below land surface.

- Rock - Areas with a soil type dominated by the presence of a shallow rock or clay layer. The shallow rock in these areas reduces the water-holding capacity and increases runoff. The magnitude of the effect on runoff depends on the depth of the rock from land surface.

- Slough - Open grassland that is nearly level and has broad drainage courses. The plant community is dominated by blue maidencane, chalky bluestem, and bluejoint panicum. Sloughs generally are found between flatwoods and freshwater marsh plant communities. Typical slough soils are Pineda, Riviera, and Holopaw. The water table may be within $254 \mathrm{~mm}$ of the soil surface for up to 6 months during most years and between depths of 254 and 1,016 $\mathrm{mm}$ for much of the remaining time. 


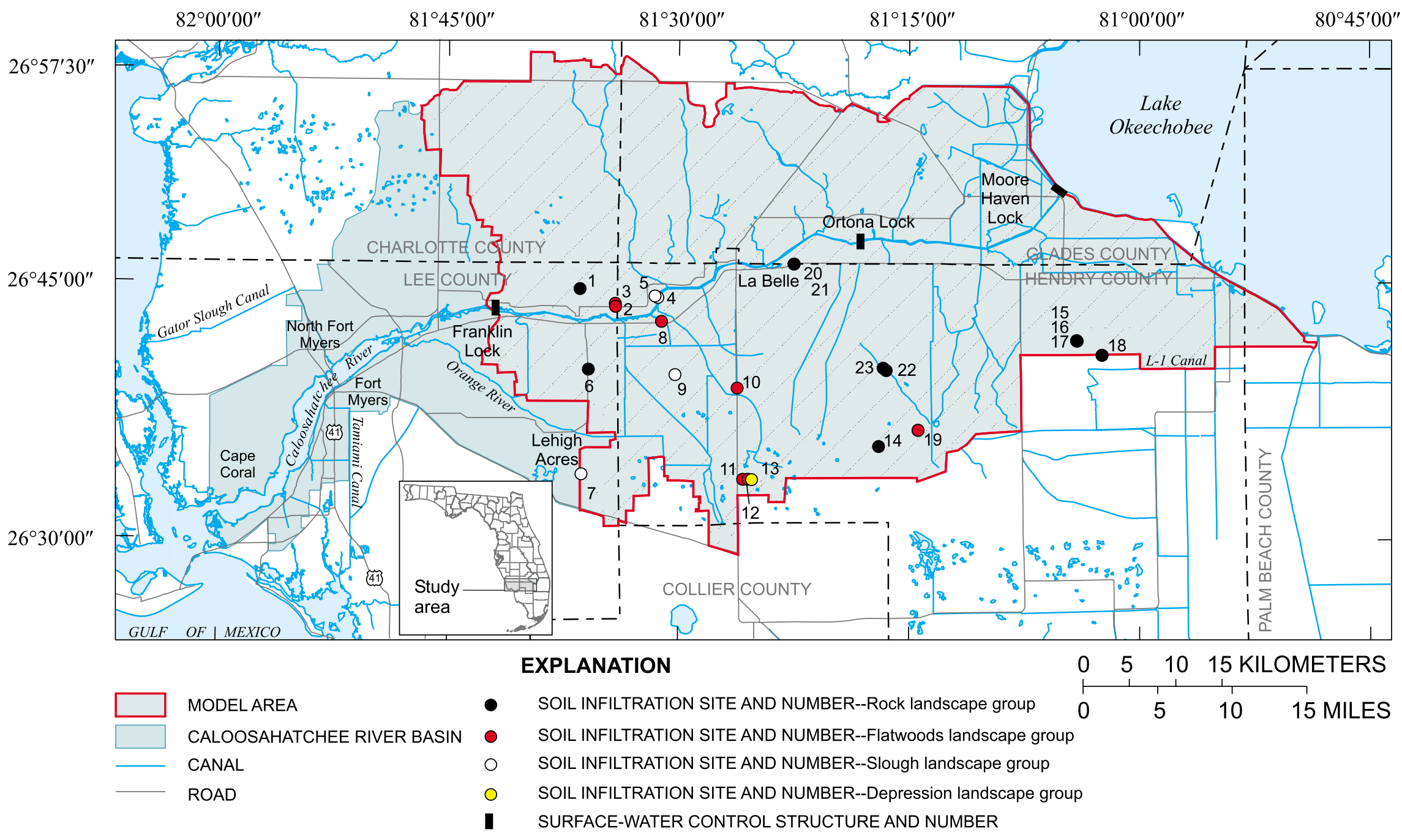

Figure 1. Caloosahatchee River Basin and location of soil infiltration sites in southwestern Florida. 
Table 1. Typical soil profiles and associated hydraulic conductivities used in the integrated surface-water and ground-water model for various landscape groups

\begin{tabular}{|c|c|c|c|}
\hline \multirow{2}{*}{ Landscape group } & \multicolumn{2}{|c|}{ Soil } & \multirow{2}{*}{$\begin{array}{c}\text { Saturated vertical hydraulic } \\
\text { conductivity } \\
\text { (centimeters per hour) }\end{array}$} \\
\hline & Type & $\begin{array}{c}\text { Depth } \\
\text { (meters) }\end{array}$ & \\
\hline \multirow[t]{5}{*}{ Depression } & Winder A1 & $0.00-0.08$ & 13 \\
\hline & Winder E & $.08-.33$ & 21 \\
\hline & Winder Btg & $.33-.58$ & 2.7 \\
\hline & Winder C1 & $.58-.89$ & 1.5 \\
\hline & Winder C3 & $.89-21.7$ & .7 \\
\hline \multirow[t]{6}{*}{ Flatwoods } & Immokalee A1 & $.00-.10$ & 72 \\
\hline & Immokalee AE & $.10-.23$ & 39 \\
\hline & Immokalee E1 & $.23-.41$ & 31 \\
\hline & Immokalee E2 & $.41-.91$ & 36 \\
\hline & Immokalee Bh2 & $.91-1.4$ & 2.2 \\
\hline & Immokalee $\mathrm{Bw} / \mathrm{Bh}$ & $1.4-23$ & 27 \\
\hline \multirow[t]{5}{*}{ Rock } & Boca A & $.00-.08$ & 40 \\
\hline & Boca E1 & $.08-.23$ & 35 \\
\hline & Boca E2 & $.23-.36$ & 29 \\
\hline & Boca Bw & $.36-.64$ & 19 \\
\hline & Boca Btg & $.64-22.64$ & .3 \\
\hline \multirow[t]{6}{*}{ Slough } & Pineda E & $.00-.13$ & 29 \\
\hline & Pineda Bwl & $.13-.33$ & 29 \\
\hline & Pineda Bw2 & $.33-.58$ & 23 \\
\hline & Pineda E1 & $.58-.91$ & 19 \\
\hline & Pineda Btg/E & $.91-1.37$ & .1 \\
\hline & Pineda $\mathrm{Cg}$ & $1.37-22$ & .4 \\
\hline
\end{tabular}

For each landscape group, a typical soil profile that generally represents the soil characteristics of the group was created for use in the ISWGW model. Model input for each soil type includes the vertical hydraulic conductivity of saturated soil (table 1).

Soil maps delineate areas dominated by one or more major types of soil. The boundary between two soil types in an area may be distinct, but more commonly is a merging of the soils where characteristics gradually change. Soils are related to geology, landform, relief, climate, and natural vegetation. The certainty of a soil type, however, can only be assured by site investigation and laboratory analysis of soil samples, which were not performed during this study.

\section{Acknowledgments}

The author wishes to thank Melinda Wolfert, Richard Krulikas, and W. Barclay Shoemaker of the USGS Miami Subdistrict for their diligent efforts in coordinating and conducting the field data-collection efforts. Appreciation is extended to Eric Flaig of the 
SFWMD for his assistance during data collection, and to Eric Swain of the USGS Miami Subdistrict for his guidance and advice throughout data collection and analysis.

\section{ESTIMATING INFILTRATION RATES OF SATURATED SOILS}

The process of water infiltrating through a surface soil is a complex interaction between rainfall intensity, soil type, and surface cover and condition. Soil surface conditions govern the ability or rate at which water passes into the soil, whereas the internal soil structure governs the rate at which water passes through the soil. Horton (1940) showed that when rainfall exceeds the infiltration rate, water infiltrates surface soils at a rate that decreases with time. According to Horton's equation:

$$
f=f_{c}+\left(f_{0}-f_{c}\right) e^{-k t},
$$

where

$f$ is the maximum infiltration rate at time $t$,

$f_{c}$ is the saturated soil infiltration rate,

$f_{0}$ is the initial infiltration rate at time equals zero,

$k$ is a constant that defines function $f$, and

$t$ is time.

Ultimately, the infiltration rate reaches a constant value known as the saturated soil infiltration rate. Rubin and Steinhardt (1963) and Rubin and others (1964) showed that the final infiltration rate reached under these conditions is equal to the vertical hydraulic conductivity of a saturated soil. Several assumptions about boundary conditions must be met, however, including a constant hydraulic gradient with depth and flow through the soil column, which is vertical (no lateral component).

\section{Soil Infiltration Measurements}

Soil infiltration measurements were made at 23 sites in the Caloosahatchee River Basin (fig. 1 and table 2). Of these sites, 11 are classified by the rock landscape group, 7 by the flatwoods landscape group, 4 by the slough landscape group, and 1 by the depression landscape group. Sites were selected with assistance from the SFWMD based on soil type, land use, proximity to water source, site accessibility, and future study needs. Access to private property limited site location in several instances; therefore, less desirable nearby sites, such as those along roadways, were used as alternatives. In all instances, sites were selected to represent the typical land use and surface conditions of the surrounding area. At four sites, a second measurement was made in proximity to the first measurement to test the reproducibility of the data-collection method and to gain further insight about spatial variability in soil infiltration.

Soil infiltration was measured by using a standard double-ring infiltrometer (American Society for Testing and Materials, 1994), which consists of two concentric rings, a driving plate, and two calibrated Marriotte tube assemblies to deliver water to the rings during the measurement (fig. 2). The inner and outer rings are driven into the ground by raising and dropping a sliding weight on the driving plate placed on top of the rings. The saturated soil between the inner and outer rings vertically constrains flow through the inner ring. For this study, water used for the soil infiltration tests was taken from local groundwater wells and nearby canals when wells were not near the test site.

The rings were filled with water to a depth of about 51 to $76 \mathrm{~mm}$. The Marriotte tubes have closed airtight tops designed to maintain a constant head in the rings by delivering water as it is lost by infiltration. The calibrated marking on the Mariotte tube generally is read at timed intervals to calculate the delivery rate of water to the inner ring. If a constant head is maintained in the inner ring, the delivery rate is the incremental infiltration rate.

At sites where the infiltration rate was higher than the maximum delivery rate of the tube to the inner ring, water was added directly to the inner ring. The additional water was recorded by measuring down to the water surface from the top of the inner ring at timed intervals. (To maintain a saturated barrier, water also had to be added directly to soil between the inner and outer rings.) During a single infiltration test, the water reservoir in the Marriotte tubes had to be replenished several times. Removal of the top of the Marriotte tube allowed water to move into the rings, and constanthead conditions had to be reestablished.

Soil infiltration tests were conducted on several irrigation control berms in the Caloosahatchee River Basin. Testing infiltration rates in the highly compacted and rocky berms was difficult, and thus, assumptions of vertical flow through the soil column were uncertain. 
Table 2. Description of soil infiltration sites in the Caloosahatchee River Basin

[Soil type and landscape group classified by the South Florida Water Management District]

\begin{tabular}{|c|c|c|c|c|c|}
\hline \multirow{2}{*}{$\begin{array}{l}\text { Site } \\
\text { no. }\end{array}$} & \multicolumn{2}{|c|}{ Site location } & \multirow{2}{*}{$\begin{array}{l}\text { Observed land use } \\
\text { and field observations }\end{array}$} & \multirow{2}{*}{$\begin{array}{l}\text { Soil } \\
\text { type }\end{array}$} & \multirow{2}{*}{$\begin{array}{l}\text { Land- } \\
\text { scape } \\
\text { group }\end{array}$} \\
\hline & Latitude & Longitude & & & \\
\hline 1 & 264433 & 813625 & $\begin{array}{l}\text { Site on side of road is in a heavily grassy area near a pasture } \\
\text { with a citrus farm about } 229 \text { meters away }\end{array}$ & Pineda & Rock \\
\hline 2 & 264342 & 813408 & Site on side of road is in a grassy area near a pasture & Immokalee & Flatwoods \\
\hline 3 & 264331 & 813406 & Site is in a citrus grove & Immokalee & Flatwoods \\
\hline 4 & 264403 & 813121 & $\begin{array}{l}\text { Site is in a citrus grove that is adjacent to the Caloosa- } \\
\text { hatchee River }\end{array}$ & Riviera & Slough \\
\hline 5 & 264408 & 813132 & Site is in a citrus grove & Riviera & Slough \\
\hline 6 & 263951 & 813552 & Site is at side of road in an area of thin grass & Boca & Rock \\
\hline 7 & 263344 & 813618 & Site is at side of road in an area of thin grass & Oldsmar & Slough \\
\hline 8 & 264239 & 813107 & $\begin{array}{l}\text { Site is about } 9 \text { meters off road in a grassy area. Some rocks } \\
\text { are deposited nearby }\end{array}$ & Immokalee & Flatwoods \\
\hline 9 & 263933 & 813013 & Site is in a citrus grove & Malabar & Slough \\
\hline 10 & 263846 & 812611 & $\begin{array}{l}\text { Site is about } 4.5 \text { meters off road in a thinly grassy area adja- } \\
\text { cent to a pasture. }\end{array}$ & Oldsmar & Flatwoods \\
\hline 11 & 263326 & 812548 & Site is on top of berm in citrus grove & Immokalee & Flatwoods \\
\hline 12 & 263326 & 812528 & $\begin{array}{l}\text { Site is on road at top of berm in citrus grove. Nearby are a } \\
\text { pumping station and an irrigation canal }\end{array}$ & Immokalee & Flatwoods \\
\hline 13 & 263326 & 812513 & $\begin{array}{l}\text { Site is on top of berm in a citrus grove within an area of tall } \\
\text { reedy weeds }\end{array}$ & Holopaw & $\begin{array}{l}\text { Depres- } \\
\text { sion }\end{array}$ \\
\hline 14 & 263523 & 811659 & $\begin{array}{l}\text { Site is adjacent to a sugar cane field. Field was very moist } \\
\text { as if irrigated recently }\end{array}$ & Holopaw, lime & Rock \\
\hline 15 & 264134 & 810406 & Site is wooded with oaks, pines, and cypress trees & Hallandale & Rock \\
\hline 16 & 264135 & 810406 & Site is wooded with cypress trees in campground & Hallandale & Rock \\
\hline 17 & 264133 & 810404 & Site is wooded with pine trees & Hallandale & Rock \\
\hline 18 & 264044 & 810227 & Site is pasture & Hallandale & Rock \\
\hline 19 & 263620 & 811424 & Site is on side of road in a grassy area adjacent to pine forest & Oldsmar & Flatwoods \\
\hline 20 & 264602 & 812230 & Site is in an open area with some trees & Boca & Rock \\
\hline 21 & 264602 & 812230 & Site is in an open area with some trees & Boca & Rock \\
\hline 22 & 263949 & 811629 & $\begin{array}{l}\text { Site is on road at top of berm in a citrus grove. Soil was } \\
\text { rocky and seemed highly compressed at surface }\end{array}$ & Pineda, lime & Rock \\
\hline 23 & 263957 & 811641 & $\begin{array}{l}\text { Site is on road at top of berm in citrus grove. Soil was rocky } \\
\text { and appeared highly compressed at surface }\end{array}$ & Pineda, lime & Rock \\
\hline
\end{tabular}


A more extensive evaluation of soil infiltration rates in these compacted disturbed soils could validate or clarify rates reported herein. Additionally, soil characteristics and landscape groups for these sites may not be appropriate for comparison with less disturbed sites having the same soil characteristics and within the same landscape groups.

\section{Regression Analysis}

Incremental soil infiltration rates, as a function of time, were plotted for each test; additionally, Horton's equation was fitted by multiple nonlinear regression to estimate $f_{c}$ (the saturated soil infiltration rate). The time-series plots were examined for fit to Horton's equation and for providing reasonable estimates of $f_{c}$ based on the observed data. In all instances, the estimated $f_{c}$ is consistent with the data and with $f_{c}$ values in the literature for soils in southern Florida. The final saturated soil infiltration rate with a 95-percent confidence interval was computed based on the standard error of the regression and the number of data points plotted.

According to Horton's equation, infiltration rates become constant with time as the soil column reaches fully saturated conditions, which occurred about 20 to 30 minutes into the test at most sites. For sites where data could not be fitted to Horton's equation, the flatness of the plotted data throughout the test suggests that saturated soil conditions may have occurred early in the test, and thus, maintained for the duration of the test. Because the characteristic curve based on Horton's equation (Horton, 1940) was not observed in the plotted data at seven sites, multiple nonlinear regression could not be used to estimate $f_{c}$ (fig. 3). Based on the assumption that saturated soil conditions were reached within the first 20 minutes of the test, the incremental soil infiltration rates measured after the first 20 minutes were averaged to estimate $f_{c}$ at these sites. The standard deviation of $f_{c}$ provides an estimate of the variability of the data at the seven sites (table 3).

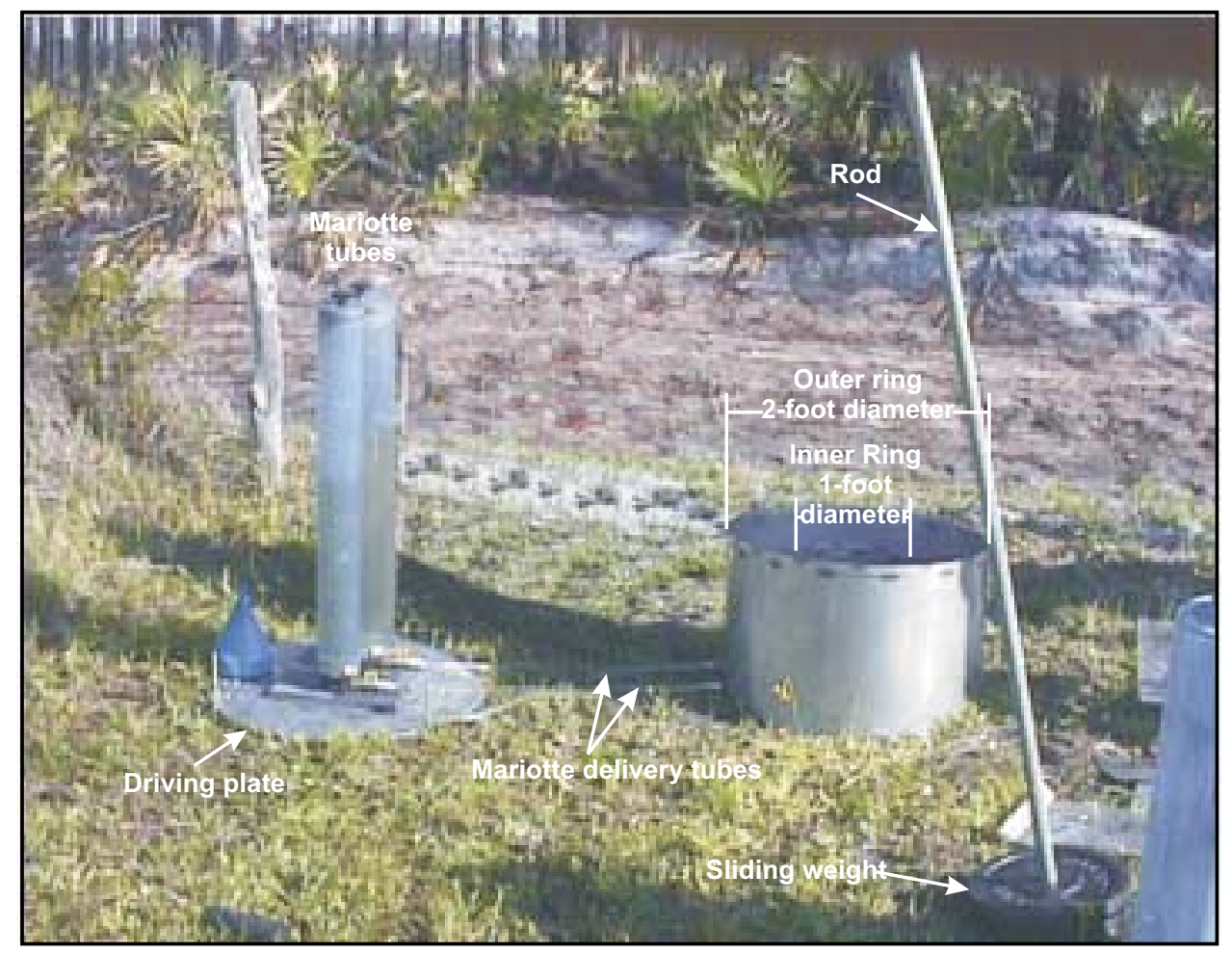

Figure 2. Double-ring infiltrometer setup. 

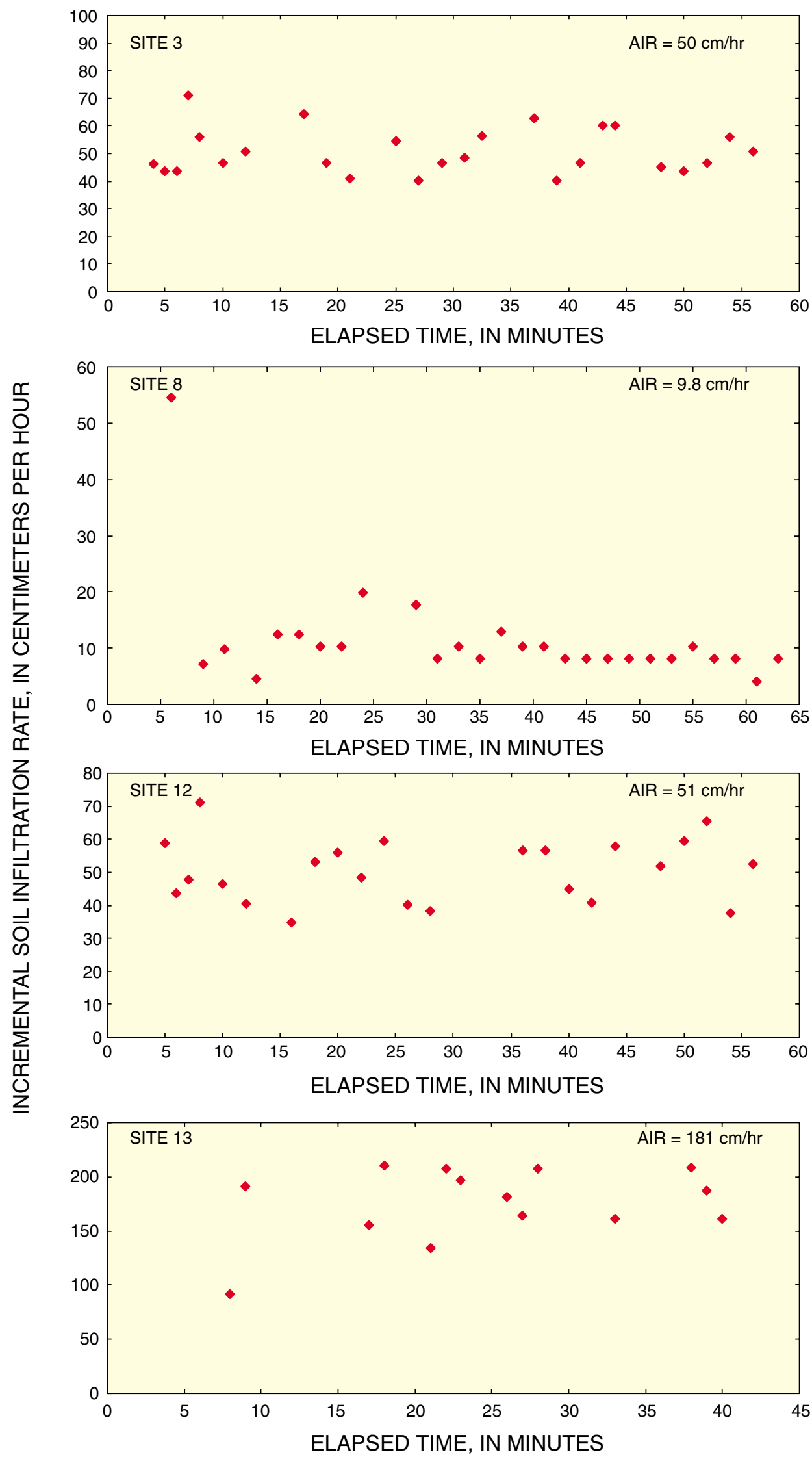

Figure 3. Soil infiltration rate as a function of time for sites where data could not be fitted to Horton's equation. The average infiltration rate (AIR) is for time periods greater than 20 minutes. 



Figure 3. Soil infiltration rate as a function of time for sites where data could not be fitted to Horton's equation. The average infiltration rate (AIR) is for time periods greater than 20 minutes--Continued. 
Table 3. Estimates of infiltration rates of saturated soils based on average incremental infiltration rates for time periods greater than 20 minutes

$\left[f_{c}\right.$, saturated soil infiltration rate. Site 13 is located on berm where soil characteristics probably vary from undisturbed or less disturbed sites within the same landscape group]

\begin{tabular}{rlcc}
\hline $\begin{array}{r}\text { Site } \\
\text { no. }\end{array}$ & $\begin{array}{c}\text { Landscape } \\
\text { group }\end{array}$ & $\begin{array}{c}\mathbf{f}_{\mathbf{c}} \\
\text { (centimeters } \\
\text { per hour) }\end{array}$ & $\begin{array}{c}\text { Standard } \\
\text { deviation } \\
\text { (centimeters } \\
\text { per hour) }\end{array}$ \\
\hline 3 & Flatwoods & 50 & 7.5 \\
8 & Flatwoods & 9.8 & 3.4 \\
12 & Flatwoods & 51 & 8.8 \\
13 & Depression & 181 & 25 \\
15 & Rock & 48 & 12 \\
20 & Rock & 64 & 14 \\
21 & Rock & 66 & 12 \\
\hline
\end{tabular}
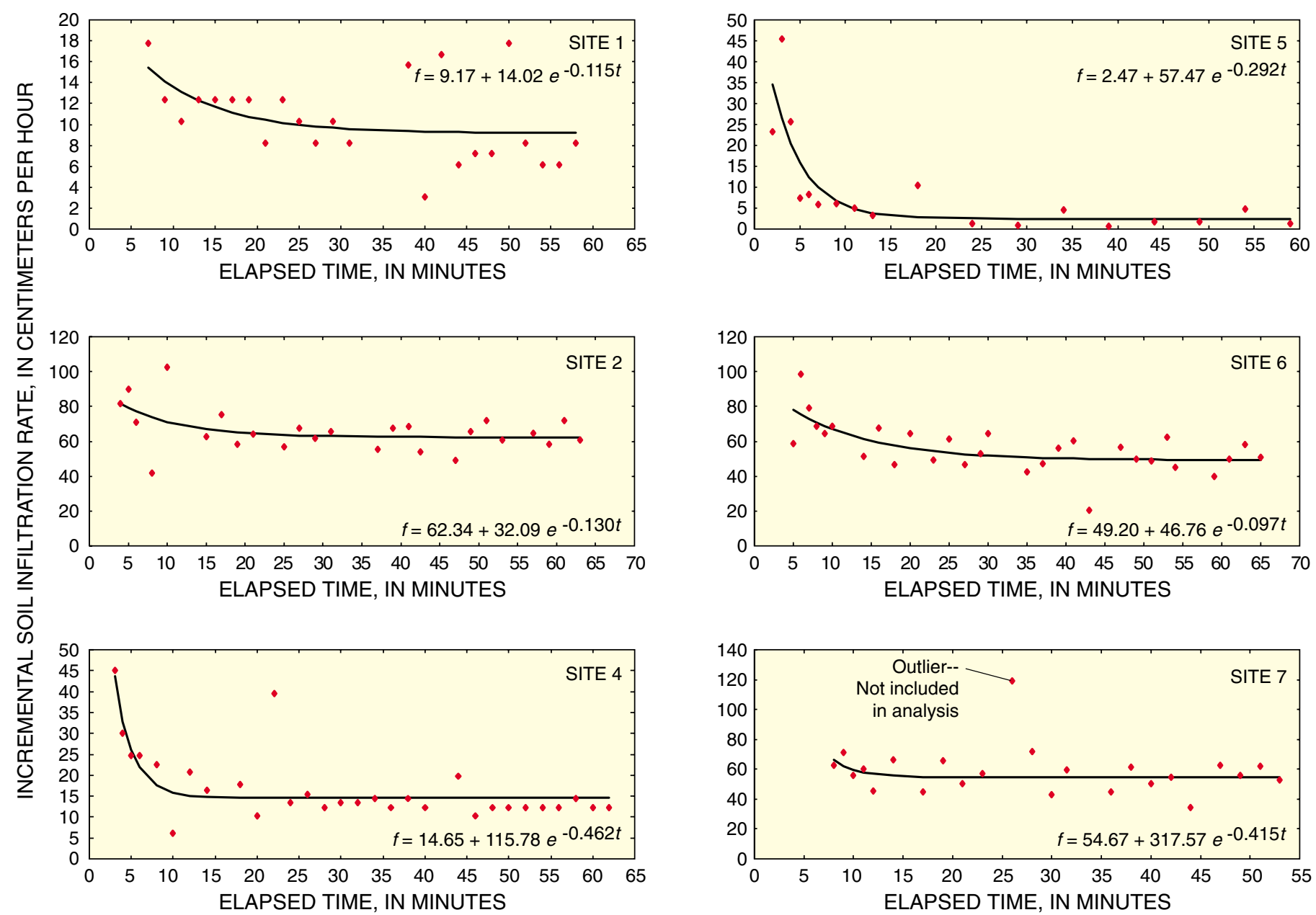

Data for 16 sites were fitted to Horton's equation by regression analysis (fig. 4). The difficulty in precisely measuring the water lost to infiltration at incremental times during the test probably resulted in the substantial amount of scatter in the plotted data. For sites 7, 16 (test 2), 19 (test 1), and 23 (test 2), the regression of Horton's equation converged only after removing an outlier value. The data were analyzed with and without outliers for site 18 (test 2); outliers were qualitatively determined. An analysis of the data suggests that removing these outliers probably is insignificant in estimating $f_{c}$. The infiltration capacities based on the regression analysis for the 16 sites and the 95percent confidence intervals for these estimates are listed in table 4.
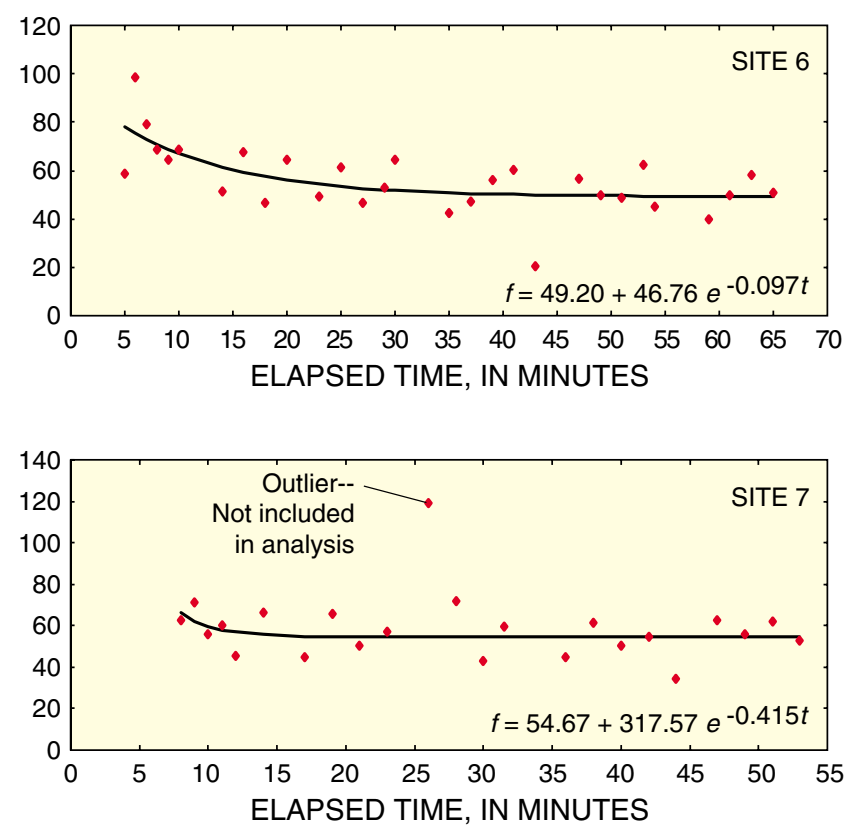

Figure 4. Soil infiltration rate as a function of time for sites fitted to Horton's equation. 

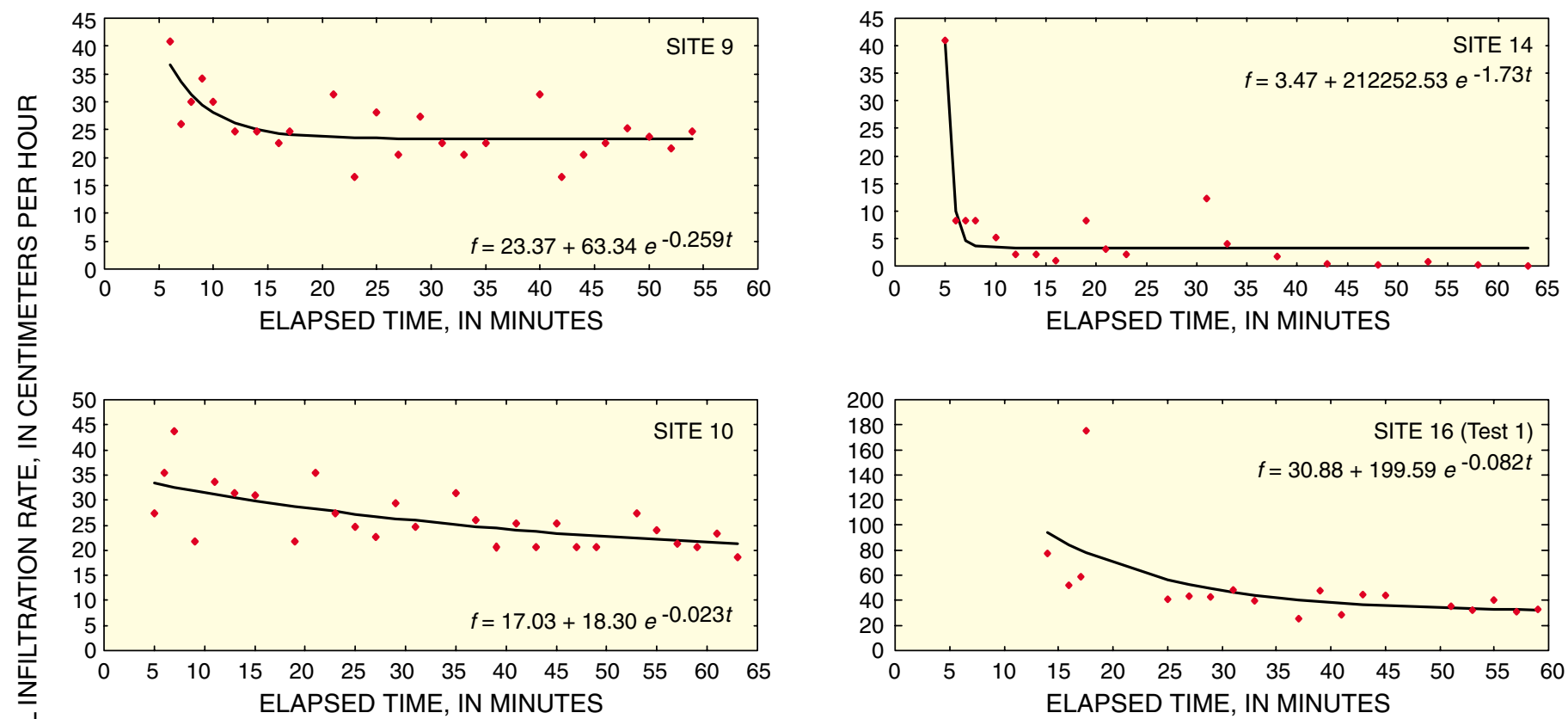

के

䫆
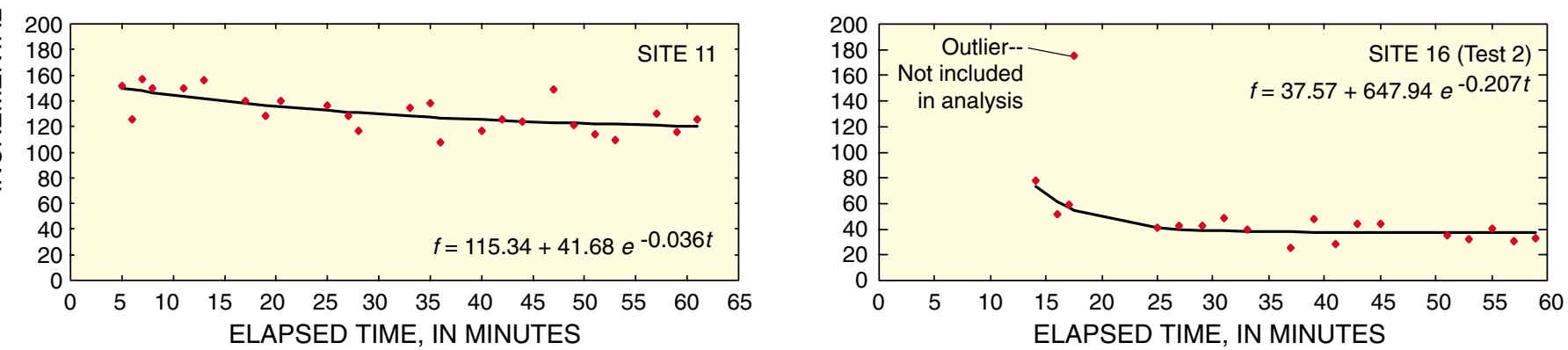

Figure 4. Soil infiltration rate as a function of time for sites fitted to Horton's equation--Continued. 

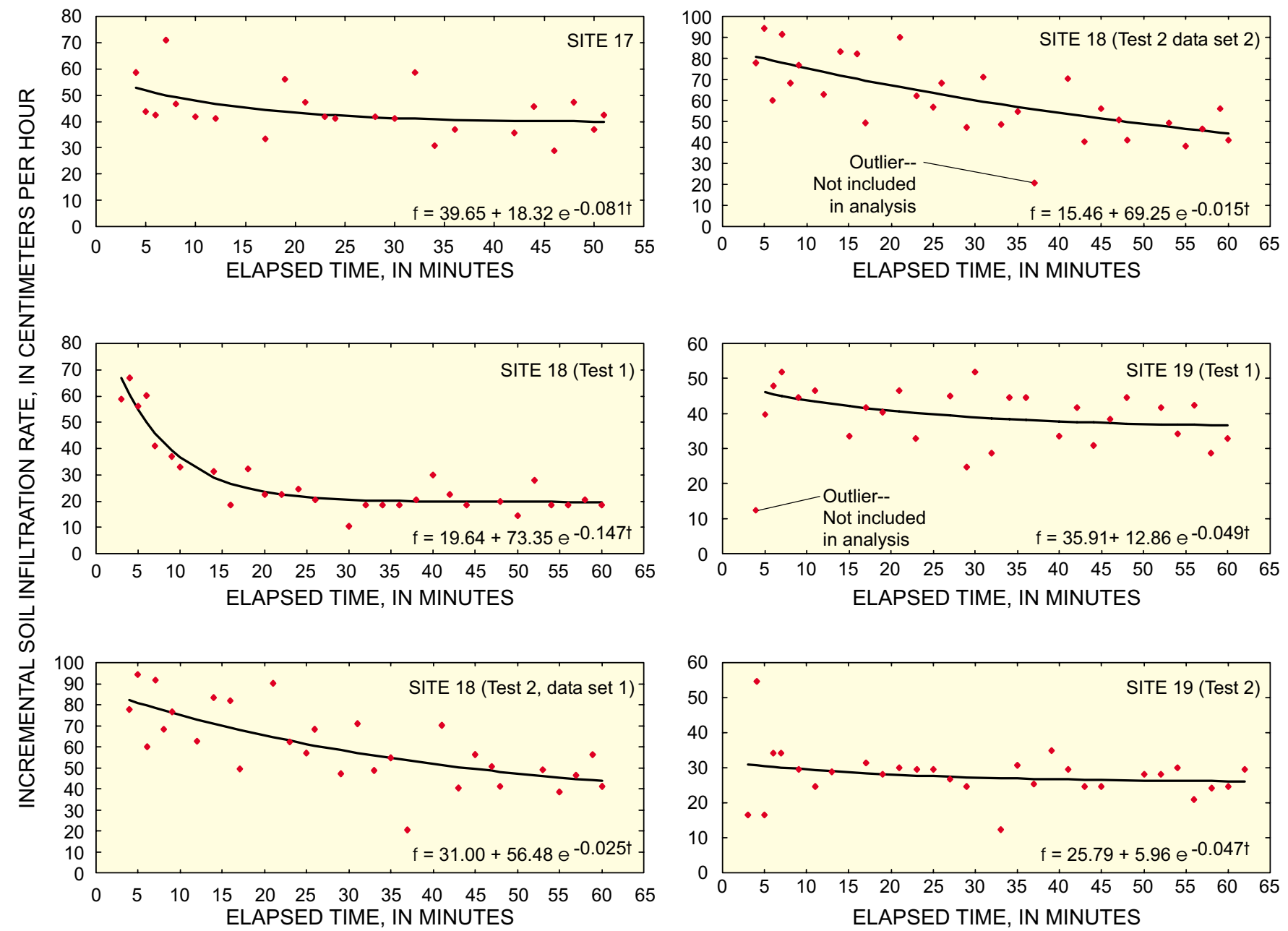

Figure 4. Soil infiltration rate as a function of time for sites fitted to Horton's equation--Continued. 


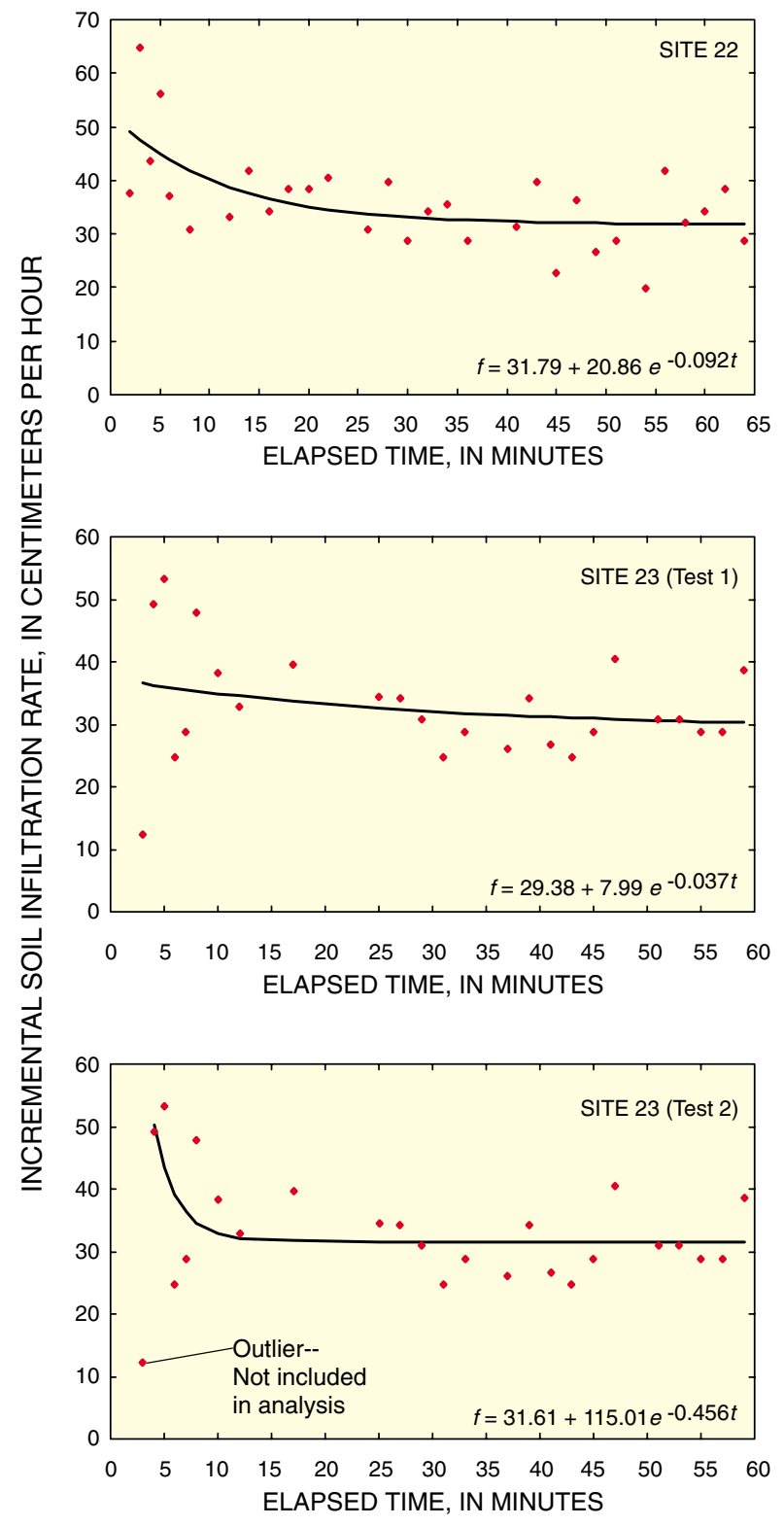

Figure 4. Soil infiltration rate as a function of time for sites fitted to Horton's equation--Continued.

Estimated $f_{c}$ values are plotted for each landscape group and compared to the lowest saturated vertical hydraulic conductivity in the top $0.5 \mathrm{~m}$ (meter) of the "typical" model soil profiles used in the ISWGW model (fig. 5). This comparison is based on the assumption that the infiltration test wetted only the top $0.5 \mathrm{~m}$ of soil - an assumption that may not have been accurate for all tests. The mean and standard deviation of the estimated $f_{c}$ are computed for the landscape groups having four or more tests.
The estimated infiltration rates of saturated soils ranged from 9.8 to $115 \mathrm{~cm} / \mathrm{hr}$ (centimeters per hour) in the flatwoods landscape group, 3.4 to $66 \mathrm{~cm} / \mathrm{hr}$ in the rock landscape group, and 2.5 to $55 \mathrm{~cm} / \mathrm{hr}$ in the slough landscape group (fig. 5). For the depression landscape group, represented by site 13 , the estimated saturated soil infiltration rate was $181 \mathrm{~cm} / \mathrm{hr}$ and the lowest saturated vertical hydraulic was $2.7 \mathrm{~cm} / \mathrm{hr}$. Five sites $(11$, $12,13,22$, and 23) were located on irrigation control berms. Infiltration rates of the highly compacted and rocky soil may not represent the rates of less disturbed soils at sites within the same landscape groups. 
Table 4. Estimates of infiltration rates of saturated soils based on regression analysis

$\left[f_{c}\right.$, saturated soil infiltration rate]

\begin{tabular}{|c|c|c|c|c|c|}
\hline $\begin{array}{r}\text { Site } \\
\text { no. }\end{array}$ & $\begin{array}{l}\text { Landscape } \\
\text { group }\end{array}$ & $\begin{array}{c}\mathbf{f}_{c} \\
\text { (centimeters } \\
\text { per hour) }\end{array}$ & $\begin{array}{l}\text { 95-percent } \\
\text { confidence interval } \\
\text { for infiltration rate } \\
\text { (centimeters per hour) }\end{array}$ & $\begin{array}{c}\text { Outlier } \\
\text { deleted } \\
\text { (yes or no) }\end{array}$ & Comments \\
\hline 1 & Rock & 9.2 & 2.6 & No & \\
\hline 2 & Flatwoods & 62 & 7.0 & No & \\
\hline 4 & Slough & 15 & 2.4 & No & \\
\hline 5 & Slough & 2.5 & 4.7 & No & \\
\hline 6 & Rock & 49 & 7.3 & No & \\
\hline 7 & Slough & 55 & 5.1 & Yes & \\
\hline 9 & Slough & 23 & 2.2 & No & \\
\hline 10 & Flatwoods & 17 & 25 & No & \\
\hline 11 & Flatwoods & 115 & 32 & No & $\begin{array}{l}\text { Located on berm where soil characteristics prob- } \\
\text { ably vary from undisturbed or less disturbed sites } \\
\text { in same landscape group }\end{array}$ \\
\hline 14 & Rock & 3.4 & 1.9 & No & \\
\hline 16 & Rock & $\begin{array}{l}31 \\
37\end{array}$ & $\begin{array}{l}35 \\
4.6\end{array}$ & $\begin{array}{l}\text { No } \\
\text { Yes }\end{array}$ & $\begin{array}{l}\text { Two tests conducted with and without outlier for } \\
\text { complete data set }\end{array}$ \\
\hline 17 & Rock & 40 & 10 & No & \\
\hline 18 & Rock & $\begin{array}{l}20 \\
31 \\
15\end{array}$ & $\begin{array}{c}2.8 \\
66 \\
162\end{array}$ & $\begin{array}{l}\text { No } \\
\text { No } \\
\text { Yes }\end{array}$ & $\begin{array}{l}\text { Two tests conducted for complete data set. Test } 1 \\
\text { conducted with outlier; test } 2 \text { conducted with and } \\
\text { without outlier }\end{array}$ \\
\hline 19 & Flatwoods & $\begin{array}{l}36 \\
26\end{array}$ & $\begin{array}{l}12 \\
11\end{array}$ & $\begin{array}{l}\text { Yes } \\
\text { No }\end{array}$ & $\begin{array}{l}\text { Two tests conducted with and without outlier for } \\
\text { complete data set }\end{array}$ \\
\hline 22 & Rock & 32 & 4.7 & No & $\begin{array}{l}\text { Located on berm where soil characteristics prob- } \\
\text { ably vary from undisturbed or less disturbed sites } \\
\text { in same landscape group }\end{array}$ \\
\hline 23 & Rock & $\begin{array}{l}29 \\
32\end{array}$ & $\begin{array}{r}25 \\
147\end{array}$ & $\begin{array}{l}\text { No } \\
\text { Yes }\end{array}$ & $\begin{array}{l}\text { Two tests conducted with and without outlier for } \\
\text { complete data set. Located on berm where soil } \\
\text { characteristics probably vary from undisturbed } \\
\text { or less disturbed sites in same landscape group }\end{array}$ \\
\hline
\end{tabular}

${ }^{\mathbf{1}}$ Estimate of $f_{c}$ for site 1 , for example, is $9.2 \pm 2.6$ centimeters per hour, with a 95 -percent confidence interval based on the data. 


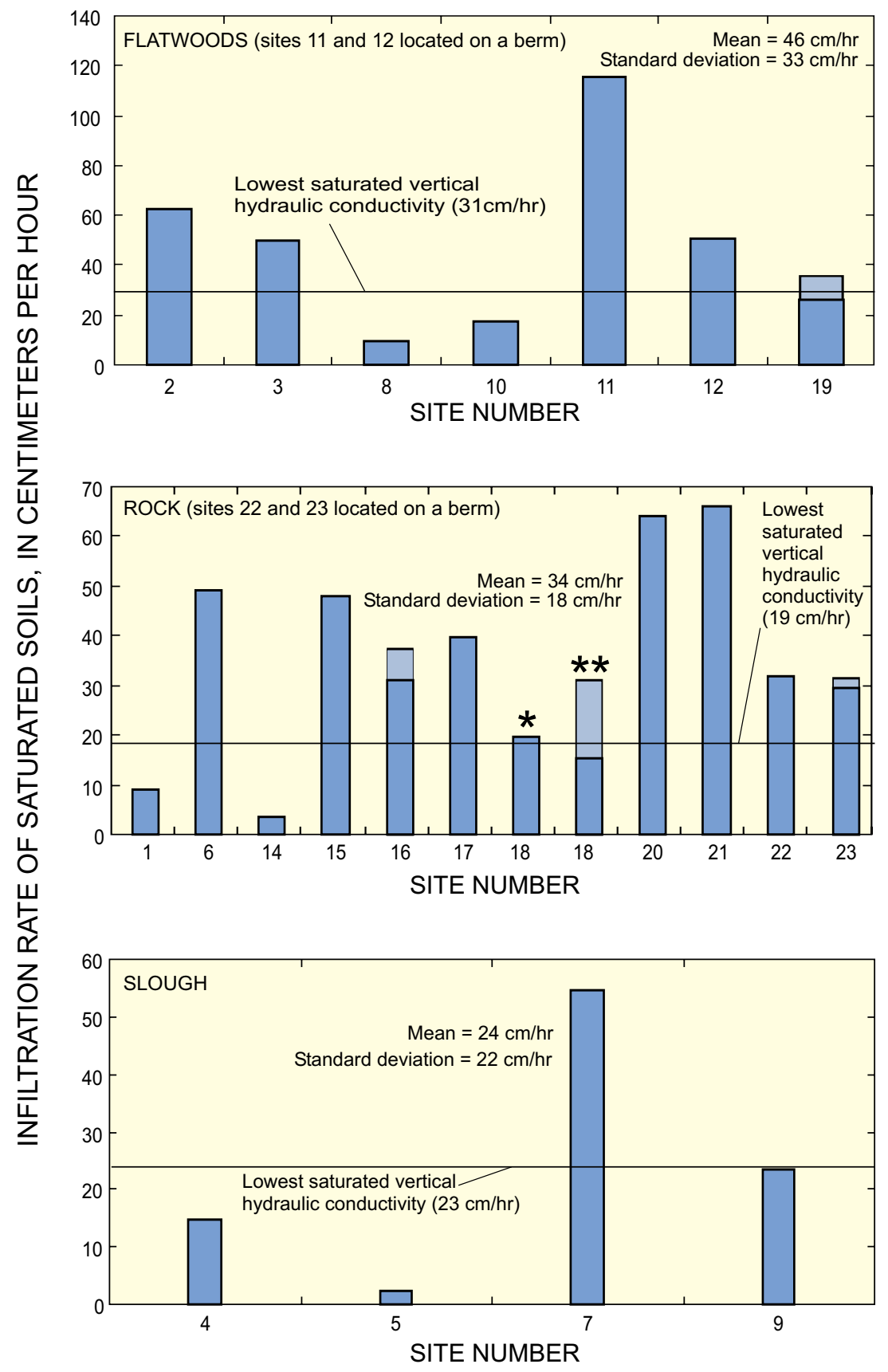

\section{EXPLANATION}

Rate determined with outlier deleted

* Data set 1

** Data set 2

NOTE: Two tests conducted at sites $16,18,19$, and 23 with and without outlier for complete data set

Figure 5. Estimated saturated soil infiltration rates for sites by landscape group compared with lowest saturated vertical hydraulic conductivity used in the integrated surface-water and ground-water model. 


\section{CONCLUSIONS}

The high infiltration rates of saturated soils in the Caloosahatchee River Basin made collection of accurate double-ring infiltrometer data difficult. Several factors influenced the tests including the fact that standard infiltrometer water-supply reservoirs could not deliver enough water at the needed rates; measuring rapidly changing water levels was difficult, and therefore, subject to inaccuracy; and local site features such as atypical root density, large rocks below land surface, or areas of compaction not visible at the surface may have affected individual test results.

Verification of assumptions used in this study requires more extensive data-collection efforts, such as using augers or backhoes to penetrate below land surface following an infiltration test to verify vertical flow, homogeneous soil profiles, and actual depth of saturation. Potentiometers could be used to verify the assumption of unit hydraulic gradient with depth. In some places where the water table is shallow, water mounding under the infiltrometer produces a "back pressure" and an equilibrium hydraulic gradient that is less than one. For this study, tests were conducted during a drought period in April 1999, when the water table was expected to be well below the soil layers saturated for this analysis.

\section{REFERENCES CITED}

American Society for Testing and Materials, 1994, Standard test method for infiltration rate of soils in field using double-ring infiltrometer: ASTM Publication D-3385-94, $7 \mathrm{p}$.

Horton, R.E., 1940, An approach towards a physical interpretation of infiltration capacity: Soils Science Society of America Proceedings, v. 5, p. 399-417.

Jacobsen, T.V., 1999, Caloosahatchee Basin Integrated Surface Water-Ground Water Model: Danish Hydraulic Institute Report, $106 \mathrm{p}$.

Rubin, J., and Steinhardt, R., 1963, Soils water relations during rain infiltration; Part I--Theory: Soils Science Society of America Proceedings, v. 27, p. 246-251.

Rubin, J., Steinhardt, R., and Reiniger, P., 1964, Soil water relations during rain infiltration: Part II--Moisture content profiles during rains of low intensities: Soils Science Society of America Proceedings, v. 28, p. 1-5. 